\title{
Chilling Prevention on Banana 'Nanica' in the Field with Bagging
}

\author{
Juliana Domingues Lima ${ }^{1}$, Danilo Eduardo Rozane ${ }^{1}$, Eduardo Nardini Gomes ${ }^{1}$, \\ Silvia Helena Modenese Gorla da Silva ${ }^{1}$, Wilson da Silva Moraes $^{2}$ \& Ricardo Alfredo Kluge ${ }^{3}$ \\ ${ }^{1}$ Universidade Estadual Paulista "Júlio de Mesquita Filho", Câmpus Experimental de Registro, Registro, Brazil \\ ${ }^{2}$ Agência Paulista de Tecnologia dos Agronegócios, Pólo Regional do Vale do Ribeira, Registro, Brazil \\ ${ }^{3}$ Dep. Ciências Biológicas, Escola Superior de Agricultura "Luiz de Queiroz", Universidade de São Paulo, \\ Piracicaba, Brazil \\ Correspondence: Juliana Domingues Lima, Universidade Estadual Paulista "Júlio de Mesquita Filho", UNESP, \\ Câmpus Experimetal de Registro, Rua Nélson Brihi Badur, n.430, Vila Tupy, CEP 11900-000, Registro, SP, \\ Brazil. Tel: 55-13-3828-3042. E-mail: judlima@registro.unesp.br
}

\author{
Received: November 20, 2017 \\ Accepted: January 3, 2018 \\ Online Published: February 15, 2018 \\ doi:10.5539/jas.v10n3p122 \\ URL: https://doi.org/10.5539/jas.v10n3p122
}

\begin{abstract}
Low temperature in the field causes chilling injury (CI) in banana and peel browning. The aim of this paper was to investigate the influence of different bagging materials and combinations on bunch development of banana (Musa AAA cv. Nanica) and the occurrence of CI. The study was carried in Jacupiranga, São Paulo, Brazil, in a completely randomized design in $2 \times 9$ factorial, two years of formation (2013 and 2014) and nine bagging materials, with eight replicates. Materials consisted in blue transparent polyethylene, white non-woven fabric, white opaque polyethylene, bubble wrap, white laminated non-woven fabric, double paper, blue transparent polyethylene plus kraft paper, blue transparent polyethylene plus white non-woven fabric and control (non-bagged). Fruits formed in both years showed low $\mathrm{L}^{*}$ and $\mathrm{C}^{*}$ values related to the $\mathrm{CI}$ index. On the coldest days of 2013 and 2014 , bagging raised the temperature by only 1.91 and $3.17^{\circ} \mathrm{C}$, respectively. Depending on the year of bunch formation, the bagging materials influenced the period between flowering and harvest, but not the bunch mass. In the green fruit, the content of chlorophylls was lower in double paper, while $\mathrm{L}^{*}$ was higher, but there were no differences in the content of phenols for the different materials. In mature fruits, CI index, $\mathrm{L}^{*}$ and $a^{*}$ were not affected by the bagging materials, unlike coordinates $b^{*}, h^{\circ}$ and $C^{*}$, which were lower for double paper, with no difference between other materials and non-bagged fruits. Bagging materials did not prevent CI and did not reduce the peel browning intensity.
\end{abstract}

Keywords: Musa, bunch cover, cold protection, low temperature, peel browning

\section{Introduction}

Bananas are grown in more than 150 tropical and subtropical countries, producing 105 million tonnes of fruit per year (Santosh et al., 2017). Low temperature is one of the factors that limits the establishment of banana plantations at certain latitudes, and has hard impact on the development of plants and fruit production and quality (Rodríguez-Zapata, 2015).

Banana fruit is extremely sensitive to chilling injury (CI), exhibiting symptoms when exposed to temperature below $12{ }^{\circ} \mathrm{C}$ (Chen et al., 2008). The symptoms are usually apparent only in the peel and include peel pitting and discoloration and abnormal ripening of pulp tissues (Chen et al., 2008), which increase with decreasing temperature (Nguyen et al., 2003).

Dysfunction of cell membrane and excess production of reactive oxygen species (ROS) are two primary events involved in CI development (Chongchatuporn et al., 2013), that induce peel browning associated with the oxidation of latex within the vascular strands (Hashim et al., 2012).

In field the bagging has been used to protect bunches from low temperatures and alleviate CI symptoms and promote changes in fruit growth (Harvey, 2005; Muchui et al., 2010; Kutinyu et al., 2014; Santosh et al., 2017; Pathak et al., 2017).

Bagging materials may differ in composition, thickness, color, opacity, degree of perforation, radiation transmissivity, number of layers, which are essential features for temperature control and efficiency CI prevention 
depending of design. The aim of this paper was to investigate the influence of different bagging materials and combinations on bunch development of banana (Musa AAA cv. Nanica) and occurrence of CI.

\section{Materials and Methods}

\subsection{Plant Material and Experimental Area}

The research was conduct at Univale farm, located at Jacupiranga, state of São Paulo, Brazil and situated at an altitude of $80 \mathrm{~m}$ above sea level, $24^{\circ} 24^{\prime} 00^{\prime \prime} \mathrm{S}$ latitude and $48^{\circ} 0^{\prime} 00^{\prime \prime} \mathrm{W}$ longitude). The climate of the region according to the Köppen's classification is Af; tropical rainy without dry season (Alvares et al., 2013). Data from a series of last 15 years, recorded by CIAGRO, Instituto Agronômico de Campinas, indicates that the mean annual minimum and maximum temperatures were $17.2^{\circ} \mathrm{C}$ and $27.4^{\circ} \mathrm{C}$, respectively, and that the average anual rainfall was $1608.2 \mathrm{~mm}$ per year. The soil is classified in the Brazilian System of Classification of Soils as Haplic Cambisol (EMBRAPA SOLOS, 2013).

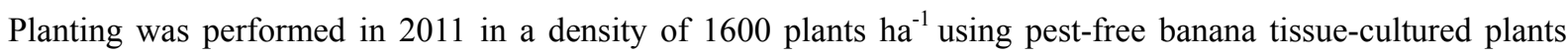
(Musa spp. AAA group, Cavendish subgroup, cv. Nanica). In research were used data from cycle 3 and cycle 4.

\subsection{Experimental Design and Treatments}

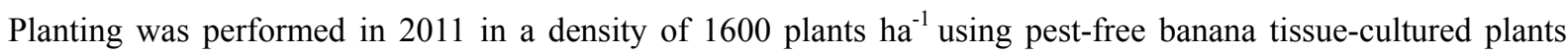
(Musa spp. AAA group, Cavendish subgroup, cv. Nanica). Banana production was evaluated in plants in two cycles and the experiment started, respectively in the last week of April 2013 and 2014. All the cultural treatments necessary for good production were carried out.

A completely randomized design in a $2 \times 9$ factorial was adopted, two years of bunch formation and nine covers, with eight replicates. The materials consisted in blue transparent polyethylene (BTP), white non-woven fabric (WNF), white opaque polyethylene (WOP), bubble wrap (BW), white laminated non-woven fabric (WLNF), double paper (DP), blue transparent polyethylene plus kraft paper (BTP+KP), blue transparent polyethylene plus white non-woven fabric (BTP+WNF); and control, non-bagged (NB) (Table 1). Bagging was carried out after the complete opening of inflorescence bracts. 
Table 1. Characteristics of bunch cover.

\begin{tabular}{|c|c|c|c|c|c|}
\hline & $\begin{array}{l}\text { Thickness } \\
\left(\mathrm{g} \mathrm{m}^{-2} \& \mu^{*}\right)\end{array}$ & $\begin{array}{l}\text { Dimension length } \\
\times \text { width }(\mathrm{m})\end{array}$ & Perforation (m) & $\begin{array}{l}\text { Number } \\
\text { of layers }\end{array}$ & Additional features \\
\hline $\begin{array}{l}\text { Blue transparent } \\
\text { polyethylene (BTP) }\end{array}$ & $3 \mu$ & $1.50 \times 0.75$ & $\begin{array}{l}0.008 \text { diameter } \\
\text { every } 0.18 \times 0.14\end{array}$ & Single & $\begin{array}{l}\text { Low density and radiation } \\
\text { transmissivity }{ }^{* *} 88.3 \% \text {. }\end{array}$ \\
\hline $\begin{array}{l}\text { White non-woven } \\
\text { fabric (WNF) }\end{array}$ & $15 \mathrm{~g} \mathrm{~m}^{-2} ; 3 \mu$ & $1.50 \times 0.80$ & Absent & Single & $\begin{array}{l}\text { With long filaments of } \\
\text { polypropylene thermally bonded } \\
\text { with hydrophilic treatment and } \\
\text { radiation transmissivity } 90.5 \% \text {. }\end{array}$ \\
\hline $\begin{array}{l}\text { White opaque } \\
\text { polyethylene (WOP) }\end{array}$ & $60 \mu$ & $1.60 \times 0.77$ & $\begin{array}{l}0.008 \mathrm{~m} \text { diameter } \\
\text { every } 0.18 \times 0.14\end{array}$ & Single & $\begin{array}{l}\text { Low density with light diffuser, } \\
\text { anti-UV and anti-viruses and } \\
76.2 \% \text { radiation transmissivity. }\end{array}$ \\
\hline Bubble wrap (BW) & $25 \mathrm{~g} \mathrm{~m}^{-2} ; 3 \mu$ & & Absent & Single & $\begin{array}{l}\text { Transparent polyethylene with air } \\
\text { bubbles on one side of the film } \\
\text { and } 88.1 \% \text { radiation } \\
\text { transmissivity }\end{array}$ \\
\hline $\begin{array}{l}\text { White laminated } \\
\text { non-woven (WLNF) }\end{array}$ & $26 \mathrm{~g} \mathrm{~m}^{-2} ; 10 \mu$ & $1.65 \times 0.80$ & Absent & Single & $\begin{array}{l}\text { With long filaments of } \\
\text { polypropylene thermally bonded } \\
\text { with hydrophilic treatment and } \\
\text { radiation transmissivity } 45.2 \% \text {. }\end{array}$ \\
\hline Double paper (DP) & $\begin{array}{l}\text { Kraft paper: } 80 \mathrm{~g} \mathrm{~m}^{-2} \\
\text { Blue paper: } 17 \mathrm{~g} \mathrm{~m}^{-2}\end{array}$ & $\begin{array}{l}\text { Kraft paper and } \\
\text { blue paper with } \\
1.70 \times 0.80\end{array}$ & Absent & Double & Radiation transmissivity $4.8 \%$. \\
\hline $\begin{array}{l}\text { Blue transparent } \\
\text { polyethylene }+ \text { Kraft } \\
\text { paper }(\mathrm{BTP}+\mathrm{KP})\end{array}$ & $\begin{array}{l}\text { Blue polyethylene: } \\
3 \mu \\
\text { Kraft paper: } \\
64 \mathrm{~g} \mathrm{~m}^{-2}\end{array}$ & $\begin{array}{l}1.50 \times 0.75 \\
0.90 \times 0.80\end{array}$ & $\begin{array}{l}\text { Polyethylene: } 0.008 \\
\text { diameter every } \\
0.18 \times 0.14 \\
\text { Kraft paper: absent }\end{array}$ & Double & $\begin{array}{l}\text { Radiation transmissivity of } 7.3 \% \\
\text { two materials. }\end{array}$ \\
\hline $\begin{array}{l}\text { Blue transparent } \\
\text { polyethylene }+ \text { white } \\
\text { non-woven fabric } \\
(\mathrm{BTP}+\mathrm{WNF})\end{array}$ & $\begin{array}{l}\text { Polyethylene: } 3 \mu \\
\text { Non-woven fabric: } \\
15 \mathrm{~g} \mathrm{~m}^{-2} ; 3 \mu\end{array}$ & $\begin{array}{l}\text { Polyethylene } \\
1.50 \times 0.75 \\
\text { Non-woven fabric } \\
1.50 \times 0.80\end{array}$ & $\begin{array}{l}\text { Polyethylene: } 0.008 \\
\text { diameter every } \\
0.18 \times 0.14 \\
\text { Non-woven fabric: } \\
\text { absent }\end{array}$ & Double & $\begin{array}{l}\text { Radiation transmissivity of } \\
66.7 \% \text { two materials. }\end{array}$ \\
\hline
\end{tabular}

Note. ${ }^{*} \mu=0.001 \mathrm{~mm} ;{ }^{* *}$ Transmissivity was measured using a portable light meter under illuminance light of $840 \mathrm{klx}$.

\subsection{Assessed Variables}

A temperature reading system was installed to collect data on the surface of fruits and the environment. For this, Datalloger Campbell Scientific, Logan, Utah, USA, Model CR 1000 was used, with data collection interval of five minutes. Mean daily temperatures and cumulative rainfall were recorded at a meteorological station (Campbell Scientific, Logan, Utah, USA) located $10 \mathrm{~km}$ from the experimental site. The thermal sum in degree-days was calculated using $14{ }^{\circ} \mathrm{C}$ as baseline temperature (Ganry \& Meyer, 1975).

Bunches were harvested when fruits from the last hand reached $3 \mathrm{~cm}$ in diameter and the number of hands (NH), bunch mass (BM) and stalk mass (SM) were recorded. Hand 1, hand 4 and the last hand of the bunch were weighed, and the number, mean diameter and length of fruits in each hand were recorded.

CI was scored visually based on the intensity of surface browning of banana of according to methodology established by Nguyen et al. (2003), as follows: 1, no CI; 2, mild injury; 3, moderate injury; 4, severe injury; 5 , very severe injury. At score 2 there is no visible browning on the skin surface but if the epidermal tissues are peeled, grayish areas are found close to the surface. At score 3 there are more such areas, which are larger and darker, and several form continuous lines. At score 4 grayish brown patches are visible on the skin. Cross section of the peel shows larger and darker areas than at score 3 . At score 5 there are relatively large dark patches on the skin surface.

\subsubsection{Chlorophylls Content}

Three peel discs (9 mm diameter) were removed from one side of fruit banana and incubated with dimethyl sulfoxide for $24 \mathrm{~h}$ in the dark (Hiscox \& Israelstam, 1979). The supernatant was used to determine the chlorophyll content according to the method of Wellburn (1994) in a spectrophotometer Shimadzu UV-1601 (Japan). 


\subsubsection{Phenolics Content}

Total phenolics in peel tissues were determined according to the Folin-Ciocalteu procedure, using the method described by Singleton et al. (1999). The extraction was carried out with ethanol by $24 \mathrm{~h}$ in the dark. Peel tissues were homogenized with methanol and extracted for $18 \mathrm{~h}$ in the dark. Then the homogenate was filtered, centrifuged. The compounds reacted with with Folin-Ciocalteu reagent and $\mathrm{Na}_{2} \mathrm{CO}_{3}$ and the quantification was conducted in a spectrophotometer Shimadzu UV-1601.

\subsubsection{Fruit Color}

The color of the peel of the green and ripe fruit was measured at four locations around equatorial region on each fruit using a colorimeter (CR-400, Minolta, Tokyo, Japan) calibrated using a standard white plate. The illuminant was D65 and color was measured using the CIE $\mathrm{L}^{*} \mathrm{a} \mathrm{b}^{*}$ system. $\mathrm{L} *$ denotes brightness $(0=$ black and $100=$ white) and chromatic co-ordinates $\mathrm{a}^{*}\left(+\mathrm{a}^{*}=\right.$ green and $\left.-\mathrm{a}^{*}=\mathrm{red}\right), \mathrm{b}^{*}\left(+\mathrm{b}^{*}=\right.$ yellow and $-\mathrm{b}^{*}=$ blue $)$. The hue angle $\left(\mathrm{h}^{\circ}\right)$ and chromaticity $\left(\mathrm{C}^{*}\right)$ were calculated by the equations below:

$$
\begin{aligned}
\mathrm{h}^{0} & =\tan ^{-1}\left(\mathrm{~b}^{*} / \mathrm{a}^{*}\right) \\
\mathrm{C}^{*} & =\left(\mathrm{a}^{* 2}+\mathrm{b}^{* 2}\right)^{1 / 2}
\end{aligned}
$$

Hand 4 was stored at $25{ }^{\circ} \mathrm{C}$ and $85-95 \%$ relative humidity up to stage 6 of the Von Loeseck scale (1950) was reached for shelf life determination and analyses in maturity.

\subsubsection{Shelf Life}

Shelf life was then determined as the number of days taken by the fruit to progress from ripeness stage 6 of the Von Loeseck (1950)

\subsubsection{Mass Loss}

Physiological losses in mass of the fruit was determined with equation on the basis of initial mass of the green fruit and loss at maturity and expressed in percent:

$$
\mathrm{ML}=[(\mathrm{Mf}-\mathrm{Mi}) / \mathrm{Mi}] \times 100
$$

Where, ML is mass loss, Mi is the initial fruit mass and Mf is fruit mass at maturity.

\subsubsection{Fruit Firmness}

Fruit firmness was measured with the help of 'Penetrometer' (Model FT-327, QA Supplies, Norfolk, VA, USA) after removing of a portion of the peel. The pressure required to force a stainless steel probe of $8 \mathrm{~mm}$ in diameter into banana was recorded and the results were given in Newtons $(\mathrm{N})$.

\subsubsection{Titratable Acidity, Soluble Solids Content and $\mathrm{pH}$}

Titratable acidity (TA) soluble solids (SS) content and $\mathrm{pH}$ were determinated after homogenizing a portion of the pulp with distilled water.Titratable acidity was measured using titration method with $0.1 \mathrm{~N} \mathrm{NaOH}$ up to $\mathrm{pH} 8.0$ in the presence of phenolphthalein (AOAC, 2005) and expressed as percentage malic acid. The $\mathrm{pH}$ was measured using a Tecnal (Piracicaba, Brazil) pH meter calibrated by pH 4 and 6.4 buffer solutions (AOAC, 2005). Total soluble solids content was determined with the help of an Atago (Japan) hand refractometer and results expressed as ${ }^{\circ}$ Brix (Tressler \& Joslyn, 1961).

\subsubsection{Content Soluble Sugars and Starch}

Soluble sugars were determined after extracting with hot ethanol and reaction with anthrone (Hodge \& Hodfreiter, 1962), and starch quantified in residue from ethanol extraction of soluble sugars (McCready et al., 1950; Patel, 1970).

\subsubsection{Dry Matter and Contents of Nutrients}

Dry matter was determined by loss mass of samples pulp and peel of $10 \mathrm{~g}$ fresh mass following $48 \mathrm{~h}$ drying in a forced air oven $\left(65 \pm 2{ }^{\circ} \mathrm{C}\right)$. The contents of nutrients were determinate in the dry matter of peel and pulp the according to Souza et al. (2016).

\subsubsection{Incidence of Disease}

Incidence of disease (Anthracnose and Crown Rot) was calculated from the number of hands with disease to the total number of hands.

\subsection{Statistical Analysis}

Data of analyses were expressed as means of three replicate determinations. Statistical analysis was conducted 
with the SISVAR software (Ferreira, 2011). Mean comparisons were performed using the Tukey's test $(\mathrm{p}<0.05)$. To determine the behavior of variables during shelf life of fruits, the study conducted regression analyses and adopted linear, quadratic or cubic models. Plots in this paper were made by Origin 8.5.

\section{Results and Discussion}

\subsection{Effect of Year of Bunch Formation}

In the period between flowering and harvest (PFH) in 2013, the average daily minimum and maximum temperatures were, respectively, 13.30 and $22.94{ }^{\circ} \mathrm{C}$, accumulated rainfall of $377 \mathrm{~mm}$, number of hours with temperature below $12{ }^{\circ} \mathrm{C}$ of 182.08 , and 5.25 hours below $5{ }^{\circ} \mathrm{C}$. In 2014 , mean temperatures were slightly higher, from 14.49 and $23.96{ }^{\circ} \mathrm{C}$, lower cumulative precipitation, equal to $296.97 \mathrm{~mm}$, number of hours with temperature below $12{ }^{\circ} \mathrm{C}$ of 72.75 and there was no temperature below $5{ }^{\circ} \mathrm{C}$. Despite the differences, bunch mass (BM) and stalk mass (SM) did not vary between years, as well as the number of leaves, which were maintained between 7 or 8 with bagging (Table 2). PFH was longer in 2013 as a reflection of lower temperatures.

Table 2. Bunch of characteristics and ripe fruits of banana cv. Nanica depending on the year of formation

\begin{tabular}{|c|c|c|c|c|c|c|c|c|c|c|}
\hline & PFH & $\mathrm{BM}$ & SM & $\mathrm{HN}$ & CI index & $a^{*}$ & $\mathrm{~b}^{*}$ & $\mathrm{~L}$ & $\mathrm{C}^{*}$ & $\mathrm{~h}^{\mathrm{o}}$ \\
\hline & -- day -- & \multicolumn{9}{|c|}{------ kg ------- } \\
\hline 2013 & $143.18 \mathrm{a}$ & 28.88 & 2.34 & 7.84 & $3,00 \mathrm{a}$ & $2.72 \mathrm{~b}$ & 45.28 & 66.08 & $42.57 \mathrm{~b}$ & $85.32 \mathrm{~b}$ \\
\hline 2014 & $120.36 \mathrm{~b}$ & 27.55 & 2.52 & 7.82 & $2,25 \mathrm{~b}$ & $3.43 \mathrm{a}$ & 43.42 & 66.12 & $46.30 \mathrm{a}$ & $86.51 \mathrm{a}$ \\
\hline Mean & 132.48 & 28.25 & 2.42 & 7.83 & 2,62 & 3.06 & 44.40 & 65.63 & 44.54 & 85.95 \\
\hline $\mathrm{vc}(\%)$ & 10.78 & 15.49 & 23.20 & 15.07 & 9,71 & 18.59 & 11.18 & 5.30 & 12.58 & 1.99 \\
\hline \multirow[t]{3}{*}{$\mathrm{F}$} & $61.03 * *$ & $0.82^{\mathrm{ns}}$ & $2.33^{\mathrm{ns}}$ & $0.08^{\mathrm{ns}}$ & $7,12 *$ & $7.63 * *$ & $2.99^{\mathrm{ns}}$ & $1.63^{\mathrm{ns}}$ & $9.39 * *$ & $10.15^{* *}$ \\
\hline & $\mathrm{SL}$ & ML & $\mathrm{F}$ & $\mathrm{pH}$ & TSS & TA & SS & $\mathrm{S}$ & DMpeel & DMpulp \\
\hline & -- day -- & -- \% -- & -- N -- & & -- ${ }^{o}$ Brix -- & -------- & ------. & --- $\%$ & ------- & ------------- \\
\hline 2013 & $8.06 \mathrm{~b}$ & 6.90 & 1,02 & $4.82 \mathrm{a}$ & 24.60 & $0.58 \mathrm{a}$ & 21.02 & 1.78 & 10.91 & $29.40 \mathrm{a}$ \\
\hline 2014 & $21.56 \mathrm{a}$ & 5.32 & 0,96 & $5.12 \mathrm{~b}$ & 23.94 & $0.57 \mathrm{a}$ & 20.63 & 1.59 & 10.90 & $27.07 \mathrm{~b}$ \\
\hline Mean & 14.81 & 6.11 & 9.73 & 4.96 & 24.27 & 0.58 & 20.83 & 1.69 & 10.90 & $28.30 \mathrm{a}$ \\
\hline ve $(\%)$ & 22.61 & 17.68 & 14.91 & 2.68 & 9.85 & 12.27 & 8.96 & 5.62 & 11.61 & $13.59 \mathrm{~b}$ \\
\hline $\mathrm{F}$ & $185.67^{* *}$ & $0.21^{\mathrm{NS}}$ & $3.97^{\mathrm{ns}}$ & $9.59 * *$ & $0.76^{\mathrm{ns}}$ & $6.37^{* *}$ & $1.23^{\mathrm{ns}}$ & $2.17^{\mathrm{ns}}$ & $0.01^{\mathrm{ns}}$ & $7.80^{* *}$ \\
\hline
\end{tabular}

Note. PFH, period between flowering and harvest; BM, bunch mass; SM, stalk mass; HN, hand number; CI, chilling injury index; coordinated $a^{*}, a^{*}$; coordinated $b^{*}, b^{*} ; L^{*}$, brightness; $C^{*}$, chromaticity; $h^{\circ}$, hue angle; SL, shelf life; PM, mass loss; F, firmness, pH; TSS, total soluble solids; TA, titratable acidity; SS, soluble sugars; S, starch; DMpeel, dry mater peel and DMpulp, dry matter pulp. Means followed by the same letters in the column did not differ from each other by the Tukey test $(\mathrm{p}<0.05)$. ${ }^{*} \mathrm{p}<0.05$; $* * \mathrm{p}<0.01$; ${ }^{\text {NS }}$, not significant to $\mathrm{F}$ test $(\mathrm{p}<$ $0.05)$.

Fruits exhibited higher CI in 2013 (Table 2), due to the higher stress intensity, in terms of number of hours and minimum temperature reached. However, there were no differences in $b^{*}$ and $\mathrm{L}^{*}$ between fruits formed in the two years. Variable $\mathrm{a}^{*}$ was lower in mature fruits in 2013, compared to 2014, as well as $\mathrm{h}^{\mathrm{o}}$ and $\mathrm{C}^{*}$, indicating less yellow peel and less color purity due to browning. The absence of variation in $\mathrm{L}^{*}$ between years indicates that brightness was more sensitive to $\mathrm{CI}$ than $\mathrm{C}^{*}$, that is, with few hours of exposure to temperature below $12{ }^{\circ} \mathrm{C}$, peel browning could already be observed.

Fruits formed in the same experimental area without exposure to cold (spring/summer) were evaluated in 2013 and 2014 to establish the desirable color (standard) for the cultivar, whose mean values were $\mathrm{L}^{*}, 73.92 ; \mathrm{h}^{\circ}, 87.59$ and $C^{*}, 51.84$. These values, when compared with those of this study (Table 4), generated negative variations, $\Delta \mathrm{L}^{*}$ of -7.84 and -7.80 , for $\Delta \mathrm{h}^{\circ}$ of -2.27 and -1.08 and for $\Delta \mathrm{C}^{*}$ of -9.27 and -5.54, respectively, in 2013 and 2014, revealing that changes in these color measures coincide with peel browning. The less pronounced variations in $h^{\circ}$ are in agreement with the observations of Ratule (2006), in which CI causes more pronounced reduction in $\mathrm{L}^{*}$ and $\mathrm{C}^{*}$. The greatest variation in $\mathrm{C}^{*}$ in fruits formed in 2013 is probably related to stress intensity. More recently, Cho et al. (2016) confirmed that the CIE L*a*b* system is suitable for evaluating banana browning; however, inspection using colorimeter does not provide color information representative of the entire surface.

Only PL, pH and DMpulp were influenced by the year of bunch formation (Table 2). Fruits harvested in 2014 
showed longer PL as well as higher $\mathrm{pH}$, and on the contrary, lower DMpulp compared to fruits harvested in 2013. According to Moradinezhad et al. (2008), the thermal units accumulated during PFH have a strong relation with PL. In 2013, in PFH, 630 degrees-days in 143.18 days, and in 2014, a little more, 736 degrees-days in only 120.36 days were recorded due to the higher temperature. This resulted in the harvesting of fruits of bunch 4 in 2013 and 2014 of average length and diameter, respectively of 3.54 and $22.66 \mathrm{~cm}$, but with more advanced physiological maturity in 2013 than in 2014, which explains the need for smaller time to reach maturation in 2013 (Table 2). Bugaud et al. (2006) also observed higher PL for banana 'Nanica' cultivar harvested with lower PFH.

Despite the differences in temperature exposure capable of causing CI in both years, there were no differences in TSS in the pulp, which is indicative of the amount of sugars in the fruit (Bugaud et al., 2013), as well as in the contents of starch and soluble sugars (Table 2).

Fruits formed in 2013 when mature had lower pulp pH when compared to those formed in 2014 (Table 2), a difference supposedly more related to metabolism during maturation than to damage to cell membranes and decompartmentalization, which is the primary effect of cold (Nguyen et al., 2003). This is because the mean F values in both years did not indicate failure of softening (Chen et al., 2008), a symptom of CI in the pulp, as well as browning.

The DMpulp of fruits formed in 2013 was higher than that of fruits formed in 2014, indicating a greater amount of photoassimilates accumulated as a result of the higher water availability, or even higher PFH (Table 2).

$\mathrm{Ca}, \mathrm{Fe}$ and $\mathrm{Zn}$ contents in the peel and $\mathrm{Ca}, \mathrm{S}, \mathrm{B}$ and $\mathrm{Cu}$ in the pulp were not influenced by the year of bunch formation (Table 3), while the Mn content in the peel and pulp was influenced by the interaction between year of bunch formation and cover. N, P, K, Mg, S, B and Cu contents were lower in the peel of fruits formed in 2014 than in those formed in 2013, as well as the $\mathrm{N}, \mathrm{P}, \mathrm{K}, \mathrm{Mg}$ and Fe contents in the pulp, a difference attributed to water availability, which affects the movement of nutrients in the soil, absorption, transportation and mobilization for fruits, since the fertilization program adopted was the same in both years. Comparing the nutrient contents with those obtained by Aquino et al. (N, P, Cu, Fe, and $\mathrm{Zn}$ ) for fruits of 'Nanica' and 'Nanicão' cultivars, it was observed that for peel, $\mathrm{N}, \mathrm{P}, \mathrm{Cu}, \mathrm{Fe}$ and $\mathrm{Zn}$ contents were lower, while $\mathrm{K}, \mathrm{Ca}, \mathrm{Mg}$ and $\mathrm{Mn}$ were higher, while for pulp, $\mathrm{N}, \mathrm{P}, \mathrm{Fe}$ and $\mathrm{Zn}$ contents were lower, since $\mathrm{K}, \mathrm{Ca}$ and $\mathrm{Mn}$ were higher and $\mathrm{Mg}$ and $\mathrm{Cu}$ contents were closer. The higher $\mathrm{K}$ and $\mathrm{Ca}$ levels are reflections of liming and fertilization, while the Mn content in peel and pulp, which was about 7 times higher, reflects soil fertility. Chillet et al. (2000) verified that banana produced in alitic and hyperferric soils exhibited high Mn content in the peel, which agrees with the fact that the soil of the experimental area is iron rich, with average content of $340 \mathrm{mg} \mathrm{dm}^{-3}$, considering both years of bunch formation.

\subsection{Effect of Bagging Materials}

Bagging increases temperature and humidity and decreases light intensity (Harvey, 2005; Elkashif et al., 2010; Vargas et al., 2010; Muchui et al., 2010; Mustaffa \& Kumar, 2012; Kutinyu et al., 2014; Sarkar et al., 2014) of banana fruits. In fact, in the coldest days of 2013 and 2014 (Figure 1), bunch cover raised the peel surface temperature compared to non-bagged fruits in up to 1.91 and $3.17{ }^{\circ} \mathrm{C}$, respectively. In this condition, the increment of temperature in WOP was the greatest, followed by BTP+WFN. However, considering $12{ }^{\circ} \mathrm{C}$ as the limiting temperature for the occurrence of CI (Nguyen et al., 2003; Chen et al., 2008), none of the materials was able to prevent stress.

WOP stands out due to the greater thickness, capacity of radiation diffusion in all directions, high radiation transmittance in the visible region, but a certain degree of opacity, which prevents the reflection of radiation in the infrared region from the fruit, concentrating heat on the inner surface of the film. As it consists of two layers that reduce heat transfer (Harvey, 2005), BTP+WNF treatment has high-transmittance polyethylene, which allows the absorption of a large part of incident radiation and its concentration on the external surface of WFN, and since it is a very porous material, prevents the loss of heat by fruits, being recommended for subtropical regions (Mustaffa \& Kumar, 2012). Harvey (2005) detected lower infrared radiation transmission by BW in relation to BTP, which explains its higher temperature conservation capacity on colder days. For the two years of bunch formation, BTP was the material that exhibited lower efficiency. For the two years of bunch formation, BTP was the material that showed lower efficiency, probably due to the lower material thickness. 
Table 3. Contents of nutrients in ripe fruits of banana cv. Nanica depending on the year bunch formation

\begin{tabular}{|c|c|c|c|c|c|c|c|c|c|c|}
\hline & $\mathrm{N}$ & $\mathrm{P}$ & $\mathrm{K}$ & $\mathrm{Ca}$ & $\mathrm{Mg}$ & $\mathrm{S}$ & $\mathrm{B}$ & $\mathrm{Cu}$ & $\mathrm{Fe}$ & $\mathrm{Zn}$ \\
\hline & \multicolumn{6}{|c|}{ - } & \multicolumn{4}{|c|}{ 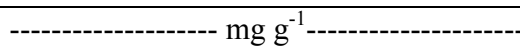 } \\
\hline \multicolumn{11}{|c|}{ Peel nutrients } \\
\hline 2013 & $11.79 \mathrm{a}$ & $1.73 \mathrm{a}$ & $68.79 \mathrm{a}$ & 2.27 & $1.42 \mathrm{~b}$ & $1.08 \mathrm{a}$ & $33.03 \mathrm{a}$ & $4.93 \mathrm{a}$ & 31.04 & 25.33 \\
\hline 2014 & $10.18 \mathrm{~b}$ & $1.58 \mathrm{~b}$ & $61.49 \mathrm{~b}$ & 2.18 & $1.31 \mathrm{a}$ & $1.06 \mathrm{~b}$ & $31.26 \mathrm{~b}$ & $4.41 \mathrm{~b}$ & 32.22 & 24.96 \\
\hline Mean & 10.99 & 1.66 & 65.15 & 2.23 & 1.36 & 1.07 & 32.15 & 4.67 & 31.63 & 25.15 \\
\hline $\mathrm{vc}(\%)$ & 7.14 & 1.73 & 7.44 & 18.32 & 19.64 & 3.38 & 9.21 & 10.91 & 21.19 & 9.33 \\
\hline $\mathrm{F}$ & $37.40 * *$ & $13.92 * *$ & $34.00 * *$ & $0.92^{\text {ns }}$ & $5.86^{*}$ & $6.94 *$ & $6.03 *$ & $32.67 * *$ & $0.71^{\mathrm{ns}}$ & $0.47^{\mathrm{ns}}$ \\
\hline \multicolumn{11}{|c|}{ Pulp nutrients } \\
\hline 2013 & $6.98 \mathrm{a}$ & $0.86 \mathrm{a}$ & $14.55 \mathrm{a}$ & 0.74 & $0.96 \mathrm{a}$ & 0.96 & 5.01 & 4.26 & $19.07 \mathrm{a}$ & 6.89 \\
\hline 2014 & $6.44 \mathrm{~b}$ & $0.84 \mathrm{~b}$ & $13.96 \mathrm{~b}$ & 0.71 & $0.95 \mathrm{~b}$ & 0.95 & 4.93 & 4.37 & $16.63 \mathrm{~b}$ & 6.15 \\
\hline Mean & 6.71 & 0.85 & 14.26 & 0.72 & 0.96 & 0.96 & 4.97 & 4.31 & 17.85 & 6.52 \\
\hline $\mathrm{vc}(\%)$ & 10.73 & 9.90 & 6.04 & 11.74 & 7.39 & 3.02 & 11.40 & 14.45 & 24.41 & 18.20 \\
\hline $\mathrm{F}$ & $9.28 * *$ & $4.45 * *$ & $5.90 *$ & $1.59^{\mathrm{ns}}$ & $5.40^{*}$ & $0.05^{\mathrm{ns}}$ & $2.27^{\mathrm{ns}}$ & $3.00^{\mathrm{ns}}$ & $7.01 *$ & $0.02^{\mathrm{ns}}$ \\
\hline
\end{tabular}

Note. N, nitrogen; P, phosphorus; K, potassium; Ca, calcium; Mg, magnesium; S, sulfur; B, boron; Cu, copper; Fe; iron; $\mathrm{Zn}$, zinc. Means followed by the same letters in the column did not differ from each other by the Tukey test $(\mathrm{p}<0.05) .{ }^{*}, \mathrm{p}<0.05 ; * * \mathrm{p}<0.01{ }^{\text {NS }}$, not significant to F test $(\mathrm{p}<0.05)$.

Fruits formed in 2014 exhibited CI symptoms when exposed to a minimum temperature of $8.90{ }^{\circ} \mathrm{C}$ (Table 2), agreeing with the report by Kutinyu et al. (2014), in which banana undergoes relatively high temperature stress in the field, condition that is frequent in the winter in the region where the experiment was conducted.

In India, the bagging of bunches of "Grande Naine" cultivar with transparent polyethylene of different thicknesses $(20$ and $40 \mu)$ and perforation percentage $\left(20,30\right.$ and 30\%) promoted a rise of up to $1.5{ }^{\circ} \mathrm{C}$ in temperature and up to $9 \%$ in relative air humidity (Sarkar et al., 2014). In Africa, the bagging of 'Grande Naine' and 'Willians' bunches with polyethylene (not-perforated and perforated) and cheese cloth bags raised the temperature by up to $3{ }^{\circ} \mathrm{C}$ when the minimum air temperature reached between 12 and $13{ }^{\circ} \mathrm{C}$, being possible to prevent CI (Kutinyu et al., 2014).

The use of thick and dark materials may cause deleterious effects to fruits due to excessive temperature rise and radiation in the spring. On the hottest day of 2013 , October 21 at $02: 15 \mathrm{pm}$, when the air temperature reached $37.13{ }^{\circ} \mathrm{C}$, the surface temperature of the fruit peel NB, BTP, WNF, WOP, BW, WLNF, DP, BTP+KP and BTP+WNF, were respectively $36.05 ; 30.74 ; 29.32 ; 31.98 ; 29.13 ; 29.43 ; 24.18 ; 27.35 ; 28.01{ }^{\circ} \mathrm{C}$. Regardless of material, bagging prevented the supra-optimal temperature $\left(31^{\circ} \mathrm{C}\right)$ (Robinson \& Saúco, 2012) from being exceeded, preventing scalding and early maturation of fruits. Under this condition, DP was the most efficient material due to the low transmissivity and high radiation reflectance.

BM was not affected by the bunch cover, but PFH, as observed by Vargas et al. (2010), with response depending on the year of bunch formation (Figure 2). In 2014, bunch bagged with DP had shorter PFH when compared to non-bagged bunches, while other materials did not differ. Due to its double layer, low radiation transmissivity and absence of perforations (Table 1), PD altered in a different way the temperature and probably gas exchanges in the atmosphere next to the fruit. The formation of the bunch in 2014, despite having occurred under a higher temperature compared to 2013, occurred under water restriction, which justifies DP having promoted lower PFH.

Modification in the atmosphere near the fruit can cause changes in the peel composition and anatomy (Amarante et al., 2002). In this study, no deleterious effects were observed on the peel caused by different bagging materials.

The reduction of the transpiration flow with bagging can alter the redistribution of nutrients to the fruit (Amarante et al., 2002). However, only the Mn content was affected by bagging materials (Figure 2), which response depended on the year of bunch formation. In 2013, there were no differences in the Mn content in the fruit peel, whereas in 2014, they were higher in bunches bagged with BW, followed by NB and lower in fruits bagged with DP and BTP+WFN. In the pulp, in 2013, the highest levels occurred in NB and BW treatments and lower in bunches bagged with DP, BTP+WFN and BTP+KP. In 2014, the difference in Mn content among materials was not significant. The greater accumulation in double-layer materials is probably due to changes in relative humidity and temperature. The high average values in the peel as previously reported, may be related to 
the excess of soil Fe content, which induces greater Mn absorption and accumulation.
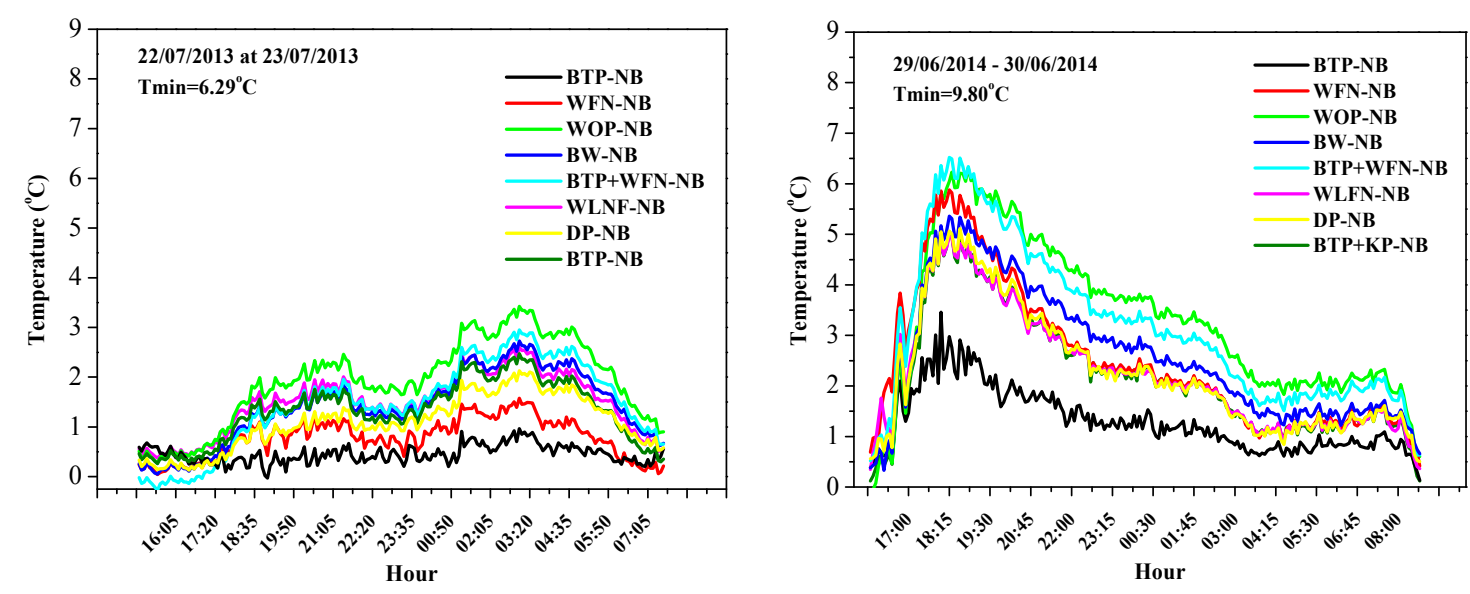

Figure 1. Difference in surface temperature of peel non-bagged and bagged with different material on the colder day of 2013 and 2014

Note. Non-bagged (NB); blue transparent polyethylene (BTP); white non-woven fabric (WNF); white opaque polyethylene (WOP); bubble wrap (BW); white laminated non-woven fabric (WLNF); double paper (DP); blue transparent polyethylene plus kraft paper $(\mathrm{BTP}+\mathrm{KP})$; blue transparent polyethylene plus white non-woven fabric $(\mathrm{BTP}+\mathrm{WNF})$. Measure taken on the hand 4 of the bunch.

The percentage of dry matter in the peel (DMpeel) was higher for BTP and lower for fruits bagged with BTP+KP (Figure 3), other treatments did not differ. There were no problems in the handling of fruits bagged with $\mathrm{BTP}+\mathrm{KP}$ in the post-harvest, which could indicate a greater possibility of physical damage due to the lower peel thickness. Aquino et al. (2014) found mean DMpeel value of $10.25 \%$ for subgroup AAA cultivar, similar to that found in this study.

Post-harvest cold stress reduced resistance to pathogens (Gamal et al., 2010). In spite of the possible differences generated in the environment of fruit growth, as well as the exposure to temperature below $12{ }^{\circ} \mathrm{C}$, the incidence of diseases was not influenced neither by the year of bunch formation nor by the bagging material. Crown Rot occurred in $97.22 \%$ of bunches, while Anthracnose occurred in $1.39 \%$.

The CI symptom is due to deterioration of chlorophyll and oxidative polymerization of phenols (Hashim et al., 2012). In the peel of green fruits, the chlorophyll content, regardless of year of bunch formation, was lower in PD while $\mathrm{L}^{*}$ was higher, as a consequence of the lower radiation transmissivity of the material (Figure 3). Other color components in the peel of green fruits were not influenced by the bagging material.

The content of chlorophylls in the peel of fruits protected with different bagging materials and not bagged was reduced during fruit maturation, with no apparent alteration of the degreening process that could be associated with CI (Figure 3). 

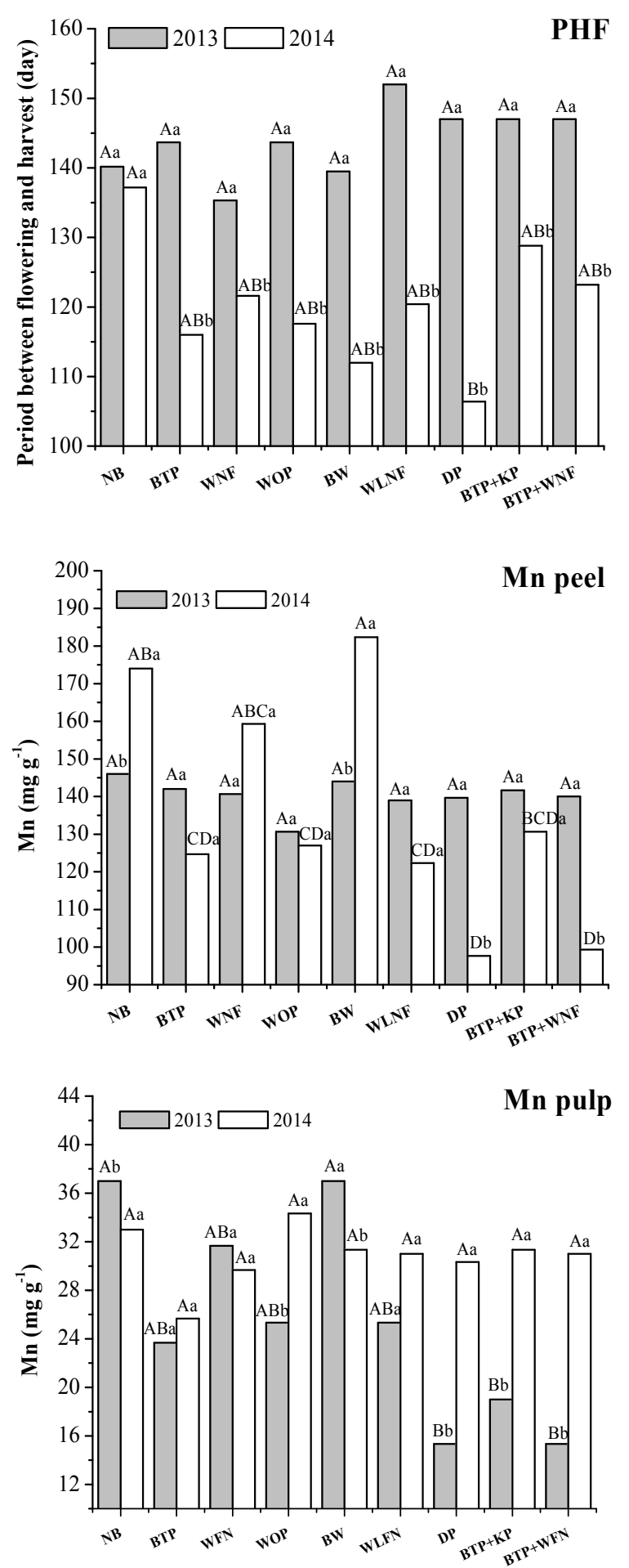

Figure 2. Period between flowering and harvest (PFH) and Mn content in fruit peel (Mn peel) ad pulp (Mn pulp) depending on bagging material and year of formation and harvest of banana cv. Nanica

Note. Non-bagged (NB); blue transparent polyethylene (BTP); white non-woven fabric (WNF); white opaque polyethylene (WOP); bubble wrap (BW); white laminated non-woven fabric (WLNF); double paper (DP); blue transparent polyethylene plus kraft paper $(\mathrm{BTP}+\mathrm{KP})$; blue transparent polyethylene plus white non-woven fabric $(\mathrm{BTP}+\mathrm{WNF})$. Means followed by the same uppercase letter, for bagging materials, within each year, or lowercase, for harvest years for each bagging material, did not differ from each by Tukey test $(p<0.05)$. 

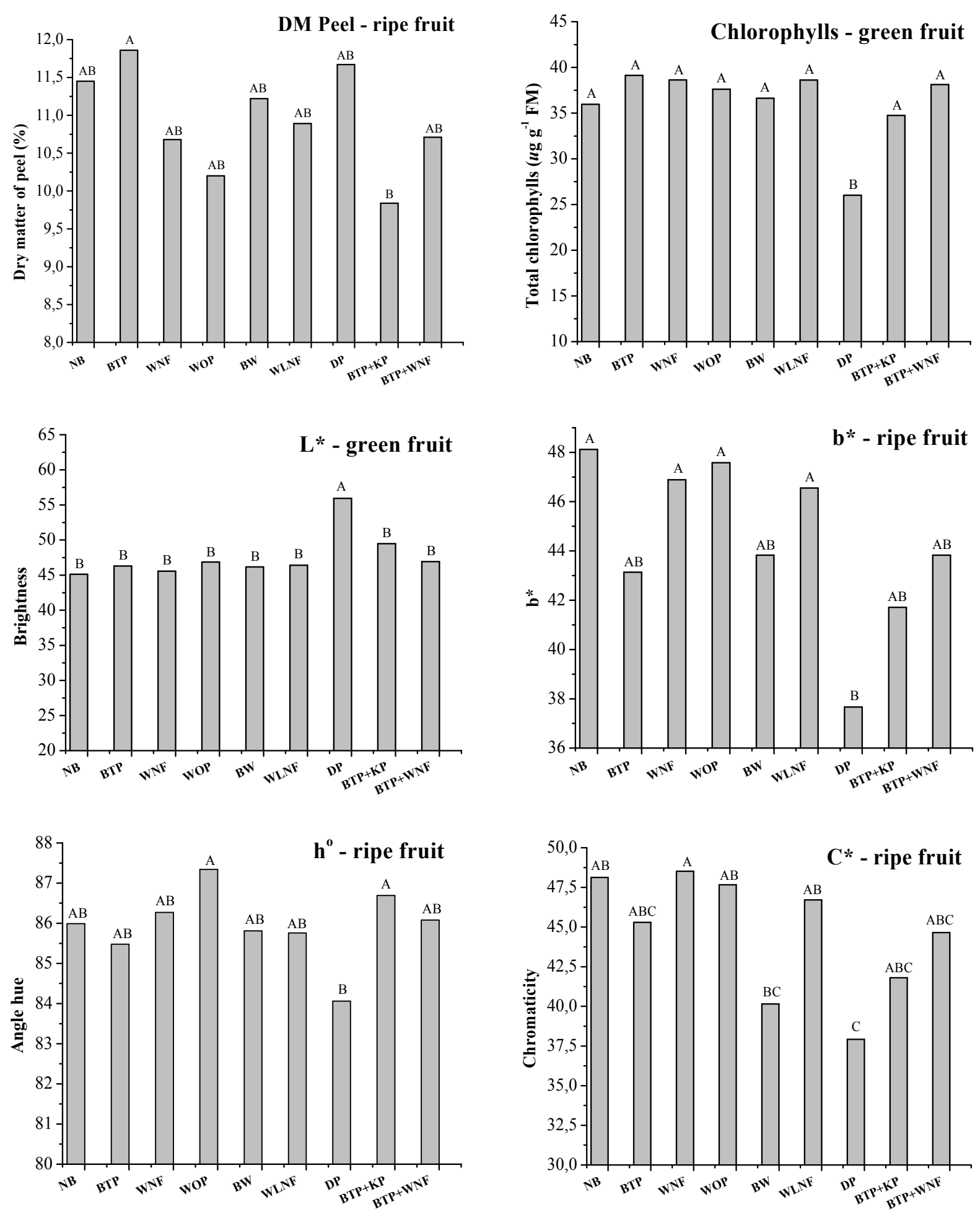

Figure 3. Dry matter, chlorophylls content and lightness in the peel of the green fruit and dry matter, coordinate $b^{*}$ $\left(\mathrm{b}^{*}\right)$, angle hue $\left(\mathrm{h}^{\circ}\right)$ and chromaticity $\left(\mathrm{C}^{*}\right)$ in the peel of the ripe fruit, depending of bagging material of banana $\mathrm{cv}$. Nanica

Note. Non-bagged (NB); blue transparent polyethylene (BTP); white non-woven fabric (WNF); white opaque polyethylene (WOP); bubble wrap (BW); white laminated non-woven fabric (WLNF); double paper (DP); blue transparent polyethylene plus kraft paper $(\mathrm{BTP}+\mathrm{KP})$; blue transparent polyethylene plus white non-woven fabric $(\mathrm{BTP}+\mathrm{WNF})$. Means followed by the same letter did not differ from each by Tukey test $(\mathrm{p}<0.05)$. 
The fact that green fruits bagged with DP showed higher L*, suggests that chlorophylls may be involved in browning (Figure 3). The content of total phenols of the peel of green fruits did not vary between the two years of bunch formation and packing material, presenting an average value of $1.85 \mathrm{mg} \mathrm{g}^{-1} \mathrm{FW}$ of peel, close to that observed by Nguyen (2003) and Rodríguez-Zapata et al. (2015) for cultivars of the same subgroup. These compounds have their synthesis induced by phenylalanine ammonia lyase (PAL) in response to low temperature in post-harvest for acclimatization (Lafuente et al., 2004). As antioxidants, they eliminate reactive oxygen species (ROS), preventing oxidation reactions, especially membrane lipids (Kondo et al., 2005). However, when the protection capacity is exceeded, cellular decomposition occurs and phenolic compounds are consumed in the oxidative degradation in polyphenol oxidase (PPO) catalyzed reaction, which results in browning. In fact, Nguyen et al. (2003) observed a reduction in the content of total free phenols, in contrast with the increase in the PAL and PPO activity of banana peel exposed to low temperature in the post-harvest period.

In the peel of ripe fruits, $\mathrm{CI}, \mathrm{L}^{*}$ and $\mathrm{a}^{*}$ were not affected by bagging materials, unlike $\mathrm{b}^{*}, \mathrm{~h}^{\circ}$ and $\mathrm{C}^{*}$, which were lower in bunches protected with DP, although there were differences among other bagging materials and non-bagged fruits (NB). This suggests that modifications in the peel color components were due only to the reduction of the available radiation.

\section{Conclusion}

The bagging materials did not promote sufficient temperature elevation capable of preventing CI, and did not induce a differentiated reduction in the peel browning intensity.

\section{Acknowledgements}

The authors are grateful to FAPESP for the financial support (2012/01167-3), to Silvio Guatura Romão, José Carlos de Mendonça and José Alberto dos Santos for the technical support.

\section{References}

Alvares, C. A., Stape, J. L., Sentelhas, P. C., Gonçalves, J. L. M., \& Sparovek, G. (2013). Köppen's climate classification map for Brazil. Meteorologische Zeitschrift, 22, 711-728. https://doi.org/10.1127/0941-2948/ 2013/0507

Amarante, C., Banks, N. H., \& Max, S. (2002). Effect of preharvest bagging on fruit quality and postharvest physiology of pears (Pyrus communis). New Zealand Journal of Crop and Horticultural Science, 30, 99-107. https://doi.org/10.1080/01140671.2002.9514204

AOAC. (2005). Official Methods of Analysis (18th ed.). Arlington: Association of Official Analytical Chemists.

Aquino, C. F., Salomão, L. C. C., Siqueira, D. L., Cecon, P. R., \& Ribeiro, S. M. R. (2014). Teores de minerais em polpas e cascas de frutos de cultivares de bananeira. Pesquisa Agropecuária Brasileira, 49, 546-553. https://doi.org/10.1590/S0100-204X2014000700007

Bugaud, C., Cazevieille, P., Daribo, M. O., Telle, N., Julianus, P., Fils-Lycaon, B., \& Mbéguié-A-Mbéguié, D. (2013). Rheological and chemical predictors of texture and taste in dessert banana (Musa spp.). Postharvest Biologyand Technology, 84, 1-8. https://doi.org/10.1016/j.postharvbio.2013.03.020

Bugaud, C., Chillet, M., Beauté, M. P., \& Dubois, C. (2006). Physicochemical analysis of mountain bananas from the French West Indies. Scientia Horticulture, 108, 167-172. https://doi.org/10.1016/j.scienta. 2006.01.024

Chen, J. Y., He, L. H., Jiang, Y. M., Wanga, Y., Joyce, D. C., Ji, Z. L., \& Lu, W. J. (2008). Role of phenylalanine ammonia-lyase in heat pretreatment-induced chilling tolerance in banana fruit. Physiologia Plantarum, 132, 318-328. https://doi.org/10.1111/j.1399-3054.2007.01013.x

Chillet, M., De Lapeyre, De Bellaire L., Dorel, M., Joas, J., Dubois, C., ... Perrier, X. (2000). Evidence for the variation in susceptibility of bananas to wound anthracnose due to Colletotrichum Musae and the influence of edaphic conditions. Scientia Horticulturae, 86, 33-47. https://doi.org/10.1016/S0304-4238(00)00138-2

Cho, J. S., Lee, H. J., Park, J. H., Sung, J. H., Choi, J. Y., \& Moon, K. D. (2016). Image analysis to evaluate the browning degree of banana (Musa spp.) peel. Food Chemistry, 194, 1028-1033. https://doi.org/10.1016/ j.foodchem.2015.08.103

Chongchatuporn, U., Ketsa, S., \& van Doorn, W. G. (2013) Chilling injury in mango (Mangifera indica) fruit peel: Relationship with ascorbic acid concentrations and antioxidant enzyme activities. Postharvest Biology and Technology, 86, 409-417. https://doi.org/10.1016/j.postharvbio.2013.07.023

Elkashif, E. M., Mohamed, H. A., \& Elamin, O. M. (2010). Effect of pre- and post-harvest treatments on yield 
and fruit quality of selected banana cultivars. Gezira Journal of Agricultural Science, 8, 1-10.

EMBRAPA SOLOS. (2013). Sistema Brasileiro de Classificação de Solos (3rd ed.). Brasilia-DF: Embrapa.

Ferreira, D. F. (2011). Sisvar: A computer statistical analysis system. Ciência e Agrotecnologia, 35, $1039-1042$. https://doi.org/10.1590/S1413-70542011000600001

Gamal, E., Ning, W., \& Clement, V. (2008). Detecting chilling injury in Red Delicious apple using hyperspectral imaging and neural networks. Postharvest Biology and Technology, 52, 1-8. https://doi.org/10.1016/ j.postharvbio.2008.11.008

Ganry, J., \& Meyer, J. P. (1975). Recherche d'une loi d'action de la température sur la croissance des fruits du bananier. Fruits, 30, 375-392.

Harvey, B. V. (2005). Mild chilling injury of banana (Cavendish cv. Williams) and its control in the field (Doctoral thesis, University of Adelaide, Adelaide, Australia).

Hashim, N., Janius, R. B., Baranyai, L., Rahman, R. A., Osman, A., \& Zude, M. (2012). Kinetic model for colour changes in bananas during the appearance of chilling injury symptoms. Food Bioprocess Technology, 5, 2952-2963. https://doi.org/10.1007/s11947-011-0646-Z

Hiscox, J. D., \& Israelstam, G. F. (1979). A method for the extraction of chlorophyll from leaf tissue without maceration. Canadian Journal of Botany, 57, 1332-1334. https://doi.org/10.1139/b79-163

Hodge, J. E., \& Hodfreiter, B. R. (1962). Determination of reducing sugars and carbohydrate. In R. C. Wilster \& M. I. Wolfron (Eds.), Methods in carbohydrates chemistry (pp.380-398). New York, NY: Academic Press.

Kondo, S., Kittikorn, M., \& Kanlayanarat, S. (2005). Preharvest antioxidant activities of tropical fruit and the effect of low temperature storage on antioxidants and jasmonates. Postharvest Biology and Technology, 36, 309-318. https://doi.org/10.1016/j.postharvbio.2005.02.003

Kutinyu, R., Fraiser, C., Ngezimana, W., \& Mudau, F. N. (2014). Evaluation of banana bunch protection materials for optimum fruit production on cultivars grown in Mozambique. Tropical Agriculture, 91, 109-115.

Lafuente, M. T., Sala, J. M., \& Zacarias, L. (2004). Active oxygen detoxifying enzymes and phenylalanine ammonia-lyase in the ethylene-induced chilling tolerance in citrus fruit. Journal of Agricultural and Food Chemistry, 52, 3606-3611. https://doi.org/10.1021/jf035185i

McCready, R. M., Guggolz, J. Silveira, V., \& Owens, M. S. (1950). Determination of starch and amylase in vegetables. Analytical Chemistry, 22, 1156-1158. https://doi.org/10.1021/ac60045a016

Moradinezhad, F., Sedgley, M., Klieber, A., \& Able, A. J. (2008). Variability of responses to 1-methylcyclopropene by banana: Influence of time of year at harvest and fruit position in the bunch. Annals of Applied Biology, 152, 223-234. https://doi.org/10.1111/j.1744-7348.2007.00206.x

Muchui, M. N., Mathooko, F. M., Njoroge, C. K., Kahangi, E. M., Onyango, C. A., \& Kimani, E. M. (2010). Effect of perforated PBL blue polyethylene bunch covers on selected postharvest quality parameters of tissue cultured bananas (Musa spp.) cv. Williams in Central Kenya. Journal of Stored Products and Postharvest Research, 1, 29-41.

Mustaffa, M. M., \& Kumar, V. (2012). Banana production and productivity enhancement through spatial, water and nutrient management. Journal of Horticultural Sciences, 7(1), 1-28.

Nguyen, T. B. T., Ketsa, S., \& Van Doorn, W. G. (2003). Relationship between browning and the activities of polyphenol oxidase and phenylalanine ammonia lyase in banana peel during low temperature storage. Postharvest Biology and Technology, 30, 187-193. https://doi.org/10.1016/S0925-5214(03)00103-0

Patel, R. Z. (1970). A note on the seasonal variations in starch content of different parts of Arabica coffee trees. East African Agricultural and Forestry Journal, 36, 1-4.

Pathak, P., Bhattacharyya, R. K., Baishya, B. K., Das, U., \& Das, J. (2017). A review of works done regarding the impact of bunch cover application in banana. International Journal of Current Microbiology and Applied Sciences, 6(7), 2181-2194. https://doi.org/10.20546/ijcmas.2017.607.256

Ratule, M. T., Osman, A., Ahmad, S. H., \& Saari, N. (2006). Development of chilling injury of 'Berangan' banana (Musa cv. Berangan (AAA)) during storage at low temperature. Journal of Food, Agriculture \& Environment, $14,128-134$.

Robinson, J. C., \& Saúco, V. G. (2012). Plátanos y bananas. Madrid: Eujoa Artes Gráficas. 
Rodríguez-Zapata, L. C., Gil, F. L. E. Y., Cruz-Martínez, S., Talavera-May, C. R., Contreras-Marin, F., Fuentes, G., ... Santamaría, J. M. (2015). Preharvest foliar applications of glycine-betaine protects banana fruits from chilling injury during the postharvest stage. Chemical and Biological Technologies in Agriculture, 2(8), 4-10. https://doi.org/10.1186/s40538-015-0032-6

Santosh, D. T., Tiwari, K. N., \& Reddy, R. G. (2017). Banana Bunch Covers for Quality Banana Production-A Review. International Journal of Current Microbiology and Applied, 6(7), 1275-1291. https://doi.org/ 10.20546/ijcmas.2017.607.155

Sarkar, S. (2014). Shooting-harvest interval and physico-chemical properties of banana (Musa AAA cv. Grand Naine) in relation to micro climate inside the bunch cover. Asian Journal of Horticulture, 9, 40-42.

Singleton, V. L., Orthofer, R., \& Lamuela-Raventos, R. M. (1999). Analysis of total phenols and other oxidation substrates and antioxidants by means of Folin-Ciocalteu reagent. Methods in Enzymology, 299, 152-178. https://doi.org/10.1016/S0076-6879(99)99017-1

Souza, H. A., Parent, S.-E., Rozane, D. E., Amorim, D. A., Modesto, V. C., Natale, W., \& Parent, L. E. (2016). Guava waste to sustain guava (Psidium guajava) agroecosystem: nutrient-balance-concepts. Frontiers in Plant Science, 7, 1-13. https://doi.org/10.3389/fpls.2016.01252

Vargas, A., Valle, H., \& González, M. (2010). Efecto del color y de la densidade del polietileno de fundas para cobrir el racimo sobre dimensiones, presentación y calidad poscosecha de frutos de banano y plátano. Agronomía Costarricense, 34, 269-285.

Von Loesecke, H. W. (1950). Bananas (2nd ed.). New York, NY: Interscience Publish Inc.

Wellburn, A. R. (1994). The spectral determination of chlorophyll a and b, as well as total carotenoids, using various solvents with spectrophotometers of different resolution. Journal of Plant Physiology, 144, $307-313$. https://doi.org/10.1016/S0176-1617(11)81192-2

\section{Copyrights}

Copyright for this article is retained by the author(s), with first publication rights granted to the journal.

This is an open-access article distributed under the terms and conditions of the Creative Commons Attribution license (http://creativecommons.org/licenses/by/4.0/). 